http://dx.doi.org/10.12775/szhf.2018.021

PIOTR ŁACIAK

Uniwersytet Śląski, Katowice, Polska

E-MAIL: PIOTR.LACIAK@US.EDU.PL

\title{
Fenomenologia transcendentalna jako prawdziwy empiryzm
}

Na temat stosunku fenomenologii do tradycji filozoficznej Husserl pisze:

W systematycznej pracy fenomenologii, postępującej naprzód od naocznych danych do abstrakcyjnych wyżyn, rozwiązują się same przez się, bez sztuk argumentacyjnej dialektyki i bez nieudolnego starania i kompromisów, przejęte $\mathrm{z}$ tradycji wieloznaczne przeciwieństwa filozoficznych stanowisk, jak przeciwieństwa między racjonalizmem (platonizmem) a empiryzmem, relatywizmem a absolutyzmem, subiektywizmem a obiektywizmem, ontologizmem a transcendentalizmem, psychologizmem a antypsychologizmem, pozytywizmem a metafizyką, teleologicznym a kauzalnym ujęciem świata ${ }^{1}$.

W tych przeciwieństwach są wprawdzie zawarte "uprawnione motywy”, ale mają one charakter „półśrodków”, stanowią „niedopuszczalne absolutyzacje tylko relatywnie i abstrakcyjnie uprawnionych jednostronności" i dlatego należy te przeciwieństwa przezwyciężyćc . Transcendentalne przezwyciężenie tych jednostronności polega na tym, że „s ub i ektywi zm może być prze-

${ }^{1}$ E. Husserl, Phänomenologische Psychologie. Vorlesungen Sommersemester 1925, hrsg. von W. Biemel, [w:] Husserliana, Gesammelte Werke, Bd. 9, Martinus Nijhoff, Den Haag 1962, s. 299-300.

${ }^{2}$ Tamże, s. 300. 
zwyciężony tylko przez najbardziej uniwersalny i najbardziej konsekwentny subiektywizm (transcendentalny)”, „relatywiz m tylko przez najbardziej uniwersalny relatywizm”, „e m p i r y z m tylko przez najbardziej uniwersalny i najbardziej konsekwentny empiryzm" itd ${ }^{3}$. Takie rozstrzygnięcie zasadniczo różni się od dialektycznego rozwiązania, w którym przeciwstawne stanowiska są do siebie odniesione, a ich synteza zachowuje je na wyższym poziomie, wnosząc do nich nowy moment ${ }^{4}$. Dialektycznemu zniesieniu przeciwieństw brakuje radykalizmu, który określa sens Husserlowskiego filozofowania, radykalizmu, zgodnie z którym „nie przyjmujemy niczego zastanego, nie uznajemy za początek niczego przejętego z tradycji”, bo „do istoty filozofii, jako nauki cofającej się do ostatecznych źródeł, należy to, że jej praca badawcza obraca się w sferach bezpośredniej intuicji”. Ten radykalizm skutkuje zupełnym przewartościowaniem klasycznych opozycji, polegającym na tym, że najbardziej uniwersalny subiektywizm okazuje się w istocie obiektywizmem, gdyż subiektywność jako uniwersalna pradziedzina bytowa jest miejscem wykazywania uprawnienia roszczenia do wszelkiej obiektywności ${ }^{6}$; analogicznie: najbardziej uniwersalny relatywizm, czyniąc zrozumiałą relatywność wszelkiego obiektywnego bytu w odniesieniu do świadomości jako absolutnej sfery bytowej, graniczy z absolutyzmem; z kolei najbardziej uniwersalny i konsekwentny empiryzm rozszerza pojęcie doświadczenia na wszelką źródłowo prezentującą naoczność, w tym również ogląd istotowy, zgodnie z zasadą, o której mówi Paul Ricoeur, że „doświadczenie właśnie w znaczeniu

\footnotetext{
${ }^{3}$ Tamże.
}

${ }^{4}$ Zob. A. Pažanin, Wissenschaft und Geschichte in der Phänomenologie Edmund Husserls, Martinus Nijhoff, Den Haag 1972, s. 117-118.

${ }^{5}$ E. Husserl, Filozofia jako ścisła nauka, przeł. W. Galewicz, Fundacja Aletheia, Warszawa 1992, s. 78, 79. Zob. A. Pažanin, dz. cyt., s. 60.

${ }^{6}$ Zob. E. Husserl, Phänomenologische Psychologie, s. 300. Precyzując określenia, Emmanuel Levinas zaznacza, że fenomenologiczny subiektywizm „w stosunku do tradycyjnego modelu obiektywności” jest „subiektywizmem »bardziej obiektywnym niż wszelka obiektywność«”. E. Levinas, Ruina przedstawienia, [w:] tenże, Odkrywajac egzystencję z Husserlem i Heideggerem, przeł. E. Sowa, IFiS PAN, Warszawa 2008, s. 138. W tym duchu sam Husserl na temat opozycji między realizmem i idealizmem pisze: „Żaden zwykły »realista « nie był nigdy tak realistyczny i tak konkretny jak ja, fenomenologiczny »idealista «". E. Husserl, Briefwechsel, [w:] Husserliana, Dokumente, Bd. 3, in Verbindung mit E. Schuhmann herausgegeben von K. Schuhmann, Teil 7: Wissenschaftlerkorrespondenz, Springer-Science+Business Media, Dordrecht 1994, s. 16. 
empirycznym jest do przekroczenia tylko w »doświadczeniu «"7. To samo odnosi się do innych przeciwieństw.

Zauważmy, że to właśnie doświadczenie jest uniwersalną sferą badania fenomenologicznego i podstawą prawomocności wszelkiego poznania, i to w sferze bezpośredniego doświadczenia, a ściślej doświadczenia transcendentalnego, wszystkie tradycyjne przeciwieństwa zostają rozwiązanie. Wszelkie problemy rozumowe bowiem, również te tradycyjnie określone jako filozoficzne, mają $\mathrm{w}$ fenomenologii swe miejsce $\mathrm{w}$ tym znaczeniu, że „Z absolutnych źródeł doświadczenia transcendentalnego, względnie naoczności ejdetycznej uzyskują one dopiero w fenomenologii swe prawdziwe sformułowanie i powszechnie stosowane drogi swego rozwiązania"s. Z tego punktu widzenia sama fenomenologia jest nie tylko najbardziej uniwersalnym subiektywizmem transcendentalnym, lecz także najbardziej uniwersalnym i konsekwentnym empiryzmem. Nie może zatem dziwić fakt, że Husserl w Filozofi jako ścisłej nauce w kontekście fenomenologicznej koncepcji nauki mówi o "prawdziwym pozytywizmie”, przyznając, że zadanie filozofii naukowej polega na tym, aby „móc przezwyciężyć sceptyczny negatywizm (mieniący się pozytywizmem) na rzecz prawdziwego pozytywizmu"'. Z kolei w Phänomenologische Psychologie twórca fenomenologii pisze wprost o idei fenomenologii empirycznej jako „uniwersalnej nauki o faktyczności” czy "nauki o uniwersum faktów”, która opiera się metodycznie na fundamencie fenomenologii ejdetycznej, przy czym fenomenologia ejdetyczna i empiryczna wzajemnie się przenikają, stanowiąc jedno prawdziwe poznanie ${ }^{10}$. W tym kontekście często wskazuje się związek fenomenologii transcendentalnej z empiryzmem, określając ją niejednokrotnie za pomocą sprzecznych określeń jako radykalny empiryzm (Max Scheler ${ }^{11}$ ), pozytywizm transcendentalny (Wilhelm Szilasi ${ }^{12}$ ), empiryzm transcendentalny (Ludwig Land-

${ }^{7}$ P. Ricoeur, Fenomenologia i hermeneutyka. Wychodzac od Husserla..., przeł. M. Drwięga, [w:] Fenomenologia francuska. Rozpoznania/interpretacje/rozwinięcia, red. J. Migasiński, I. Lorenc, IFiS PAN, Warszawa 2006, s. 197. Zob. E. Husserl, Phänomenologische Psychologie, s. 300 .

${ }^{8}$ E. Husserl, Phänomenologische Psychologie, s. 299.

${ }^{9}$ E. Husserl, Filozofia jako ścisła nauka, s. 77.

${ }^{10}$ E. Husserl, Phänomenologische Psychologie, s. 298-299.

${ }^{11}$ Zob. M. Scheler, Postawa fenomenologiczna, przeł. A. Węgrzecki, [w:] A. Węgrzecki, Scheler, Wiedza Powszechna, Warszawa 1975, s. 132.

${ }_{12}$ Zob. W. Szilasi, Einführung in die Phänomenologie Edmund Husserls, Max Niemeyer Verlag, Tübingen 1959, s. 116-117. 
grebe $^{13}$, Natalie Depraz ${ }^{14}$ ) czy empiryzm ejdetyczny (Vittorio De Palma ${ }^{15}$ ). Zgodnie z fenomenologiczną zasadą rozwiązywania przeciwieństw w doświadczeniu transcendentalnym ten „najbardziej uniwersalny i najbardziej konsekwentny empiryzm" można nazwać - w analogii do prawdziwego pozytywizmu - „prawdziwym empiryzmem”.

\section{Pozytywistyczne a zarazem antynaturalistyczne implikacje zasady wszelkich zasad fenomenologii}

W księdze pierwszej Idei czystej fenomenologii i fenomenologicznej filozofii na temat zasady wszelkich zasad fenomenologii czytamy:

[...] że każda źródłowo prezentująca naoczność jest źródłem prawomocności poznania, że wszystko, cosię nam w „intuicji” źródłowo (by się tak wyrazić: w swej cielesnej rzeczywistości) przedstawia, należy po prostu przyjąć jako to, jako co się prezentuje, ale takżejedynie w tych granicach, w jakich się tu prezentuje ${ }^{16}$.

W ujęciu Husserla zasadę wszelkich zasad można potraktować jako ostateczną motywację samej redukcji fenomenologicznej, ponieważ zasada ta postuluje ograniczenie badania do sfery naocznych danych, a w konsekwencji zawieszenie (epoché) wszelkich przeświadczeń, założeń czy teorii, które nie dają się intuicyjnie wykazać. Zawieszenie to skutkuje odsłonięciem zakrytej $\mathrm{w}$ nastawieniu naturalnym korelacji między przedmiotami i ich sposobami naocznego dania, korelacji noetyczno-noematycznej, w ramach której

${ }^{13}$ Zob. L. Landgrebe, Der phänomenologische Begriff der Erfahrung, [w:] tenże, Faktizität und Individuation. Studien zu den Grundfragen der Phänomenologie, Felix Meiner Verlag, Hamburg 1982, s. 61.

${ }^{14}$ Zob. N. Depraz, Transcendentalna empiryczność fenomenologii, przeł. A. Dwulit, [w:] Główne problemy współczesnej fenomenologii, red. J. Migasiński, M. Prokropski, Wydawnictwo Uniwersytetu Warszawskiego, Warszawa 2017, s. 97-129.

${ }^{15}$ Zob. V. De Palma, Ist Husserls Phänomenologie ein transzendentaler Idealismus?, „Husserl Studies" 2005, vol. 21, s. 200.

${ }^{16}$ E. Husserl, Idee czystej fenomenologii i fenomenologicznej filozofi. Księga pierwsza, przeł. D. Gierulanka, PWN, Warszawa 1975, s. 73. 
przedmiot zostaje potraktowany jako noemat, to znaczy korelat noez, wzięty dokładnie tak, jak się jawi w przeżyciach. Innymi słowy, postępować zgodnie z zasadą wszelkich zasad, to ujmować wszelkie przedmioty tak, jak się we własnej osobie prezentują, a wszystko, co przekracza granice takiej prezentacji, w szczególności transcendujące korelację noetyczno-noematyczną przeświadczenie o realnym istnieniu świata (jego istnieniu „w sobie”), „brać w nawias", dokonując redukcji fenomenologicznej. Dlatego Husserl w Idei fenomenologii powie, że redukcja fenomenologiczna, stanowiąca początek filozoficznego namysłu, oznacza „ograniczenie do sfery c z y s t y ch d a n y ch s a m o prez e n a c ji, do sfery tego, o czym nie tylko się mówi i mniema, także nie do sfery tego, co spostrzeżone, lecz tego, co dane jest dokładnie w tym sensie, w jakim jest domniemane, i to dane samoobecnie w najściślejszym sensie, w ten sposób, że nic z tego, co domniemane, nie jest nie dane" 17 .

W Ideach I Husserl przyznaje, że kierując się zasadą wszelkich zasad jako zasadą wolności od przesądów, które deformują nasze widzenie przedmiotów, fenomenolodzy w istocie hołdują idei pozytywizmu:

Jeżeli „p o z y t y w i z m” znaczy tyle, co absolutnie pobawione przesądów oparcie wszystkich nauk na tym, co „pozytywne”, tj. na tym, co da się źródłowo uchwycić, to prawdziwymi pozytywistami jesteśmy $\mathrm{m}^{18}$.

W tym kontekście Max Scheler akcentuje związek między fenomenologią i pozytywizmem. Określając fenomenologię jako postawę bezpośredniego obcowania $\mathrm{z}$ samymi rzeczami $\mathrm{w}$ aktach przeżywania, pisze on bowiem:

W tym sensie - ale też jedynie w nim - fenomenologiczna filozofia jest najbardziej radykalnym empiryzmem i pozytywizmem: dla wszystkich pojęć, dla wszystkich twierdzeń i formuł, także dla twierdzeń czystej logiki, na przykład dla zasady tożsamości, należy szukać „pokrycia” w takiej zawartości przeżywania. A wszelka prawdziwość i ważność twierdzeń zostaje zawieszona, dopóki to wymaganie nie jest spełnione ${ }^{19}$.

${ }^{17}$ E. Husserl, Idea fenomenologii. Pięć wykładów, przeł. J. Sidorek, PWN, Warszawa 1990, s. 73-74.

${ }^{18}$ E. Husserl, Idee czystej fenomenologii i fenomenologicznej filozofii, s. 65.

${ }^{19}$ M. Scheler, dz. cyt., s. 132. 
Z kolei Wilhelm Szilasi, komentując wypowiedź Husserla z Idei I odnośnie do fenomenologii jako pozytywizmu, zauważa, że fenomenologia jest ekstremalnym pozytywizmem, który określa on mianem pozytywizmu transcendentalnego ${ }^{20}$. Taki pozytywizm zasadniczo różni się od ukształtowanego w tradycji naiwnego pozytywizmu, który jest jednostronnie nakierowany na zewnętrzny świat i bezkrytycznie afirmuje jego istnienie, absolutyzując je zarazem i zawężając źródłowo prezentującą naoczność do naoczności zmysłowej. W przeciwieństwie do naiwnego pozytywizmu, pozytywizm transcendentalny „oznacza, że filozofia odnosi się do czegoś pozytywnego, jednak nie do czegoś naiwnie uznanego w bycie, lecz do tego, co pozytywne uzyskanego w redukcjach, do przedmiotu transcendentnego, który świadomość oczyściła do przedmiotu ujmowalnego receptywnie"21. Ściśle mówiąc, filozofia odnosi się do przedmiotu transcendentnego ukonstytuowanego przez świadomość, to znaczy przedmiotu transcendentnego jako noematu (fenomenu), korelatu noez, zgodnie z zasadą, że transcendentalna konstytucja świata jest wyrazem korelacji między aktualnie doświadczającą świadomością i światem, korelacji, jaką suponuje sama zasada wszelkich zasad.

Husserl przyznaje, że zasadą wszelkich zasad kieruje się również badacz przyrodnik, formułując twierdzenia na temat przyrody, ponieważ „dla każdego twierdzenia odnoszącego się do faktów przyrodniczych należy pytać o doświadczenia, które je uzasadniają"22, przy czym dla badacza przyrody "źródłowo prezentującym doświadczeniem jest spostrzeżenie” w zwykłym, naturalnym znaczeniu ${ }^{23}$. Z chwilą jednak, gdy ten rodzaj naoczności przyrodoznawca uznaje za jedyne źródło uprawnienia twierdzeń, ulega on naturalistycznym przesądom, skutkującym zawężeniem pola wszelkiego prawomocnego badania do przedmiotów doświadczenia zmysłowego. Husserlowska fenomenologia demaskuje ten naturalistyczny przesąd, absolutyzujący doświadczaną zmysłowo rzeczywistość, przesąd prowadzący w istocie do zaślepionego zabobonem faktu sceptycznego światopoglądu. Zdaniem Husserla nie można bowiem utożsamić źródłowo-prezentującej naoczności z naocznością zmysłową:

[...] nie tylko zmysłowe, doświadczające widzenie, ale widzenie w og ó le jakoźródłowo-prezentująca świadomość - obojętnie

\footnotetext{
${ }^{20}$ Zob. W. Szilasi, dz. cyt., s. 116-117.

${ }^{21}$ Tamże, s. 117.

${ }^{22}$ E. Husserl, Idee czystej fenomenologii i fenomenologicznej filozofii, s. 74.

${ }^{23}$ Tamże, s. 14.
} 
jakieg o rodzaju - jest ostatecznym źródłem uprawnienia wszelkich rozumnych twierdzeń ${ }^{24}$.

Na tej podstawie Husserl wyprowadza następujący wniosek:

My nie pozwalamy naprawdę żad $\mathrm{n}$ e mu autorytetowi, by odbierał nam prawo do uznawania wszelkich rodzajów naoczności za równoważne źródła prawomocności poznania - autorytetowi „nowoczesnego przyrodoznawstwa” także na to nie pozwalamy ${ }^{25}$.

W konsekwencji „za doświadczenie podstawiamy coś ogólniejszego - »naoczność« - i tym samym odrzucamy utożsamienie nauki w ogóle z nauką doświadczalną"26.

Zasada wszelkich zasad nie implikuje zatem zawężenia pola badań do tego, co dane w naoczności zmysłowej, lecz, przeciwnie, jego rozszerzenie na to, co dane w naoczności niezmysłowej, to znaczy na sferę czystych istot i ugruntowanych $w$ nich praw. Zawężenie takie jest typowe dla naturalisty jako naiwnego pozytywisty dlatego, że pozostaje on jednostronnie zorientowany na świat faktów, przecząc możliwości poznania istot, odpowiadających sensom ogólnych twierdzeń, jakie wypowiada. W konsekwencji badacz naturalista, zaślepiony zabobonem faktu, nie dostrzega, że „k a ż d a $\mathrm{n}$ a u k a o faktach (nauka doświadczalna) ma istotne teoretyczne podstawy w ejdetycznych ontologiach"27, że eidos stanowi warunek poznania wszelkich faktów w tym znaczeniu, iż „każde racjonalne wytłumaczenie faktu odsyła [...] do pewnego apriori”28, że wszelki sąd o faktach implikuje odnośną istotę. W odróżnieniu od naiwnego pozytywizmu, fenomenolog wykazuje tym samym istnienie czystych istot, które są specyficznym przedmiotem badań fenomenologii, przy czym zgodnie z zasadą wszelkich zasad mówienie o istotach jako przedmiotach idealnych byłoby bezzasadne, gdybyśmy nie wskazali aktów, w których są one dane. Sama fenomenologiczna zasada wszelkich zasad bowiem, wyrażając korelację między podstawowymi gatunkami aktów świadomości i zasadniczymi gatunkami przedmiotów, suponuje, że ontologiczne rozróżnienia przedmiotowe, jak

\footnotetext{
${ }^{24}$ Tamże, s. 62.

${ }^{25}$ Tamże, s. 65.

${ }^{26}$ Tamże, s. 63.

${ }^{27}$ Tamże, s. 34.

${ }^{28}$ E. Husserl, Medytacje kartezjańskie, przeł. A. Wajs, PWN, Warszawa 1982, s. 234.
} 
realny czy idealny, są ugruntowane $\mathrm{w}$ fenomenologicznych rozróżnieniach sposobów dania ${ }^{29}$. Mając na uwadze uniwersalną korelację między przeżyciami i przedmiotami, twórca fenomenologii w Kryzysie nauk europejskich pisze wprost:

Doświadczenie, oczywistość, nie mają charakteru pustej ogólności, lecz różnicują się odpowiednio do rodzajów, gatunków i kategorii dziedzinowych tego, co istnieje, a także ze względu na wszelkiego rodzaju modalności czasoprzestrzenne. To, co istnieje, w jakimkolwiek sensie, konkretnym lub abstrakcyjnym, realnym bądź idealnym, ma własne sposoby samoprezentacji, a po stronie Ja - swoje rodzaje intencji w modi obowiązywania i należące do nich rodzaje subiektywnych przemian obowiązywania w syntezach zgodności i niezgodności jednopodmiotowej i intersubiektywnej $j^{30}$.

W ten sposób Husserl dochodzi do pojęcia naoczności niezmysłowej, wykazując, że przedmioty realne są dane w aktach spostrzeżenia zmysłowego, podczas gdy przedmioty irrealne - w aktach naoczności kategorialnej (niezmysłowej). W tym kontekście w Ideach I czytamy:

Istota (eidos) jest nowego rodzaju przedmiotem. Tak jak tym, co dane w indywidualnej naoczności albo naoczności doświadczeniowej, jest indywidualny przedmiot, tak tym, co dane w naoczności istotnościowej, jest czysta istota ${ }^{31}$.

\section{Fenomenologia jako krytyka racjonalistycznych przesądów}

Formułując zasadę wszelkich zasad, Husserl występuje nie tylko przeciwko empirystycznym przesądom, naturalistycznie zawężającym pojęcie naoczności, lecz także przeciwko przesądom intelektualistycznym, które doprowa-

${ }^{29}$ Zob. E. Tugendhat, Der Wahrheitsbegriff bei Husserl und Heidegger, Walter de Gruyter \& Co, Berlin 1967, s. 113, 240.

${ }^{30}$ E. Husserl, Die Krisis der europäischen Wissenschaften und die transzendentale Phänomenologie. Eine Einleitung in die phänomenologische Philosophie, hrsg. von W. Biemel, Husserliana, Gesammelte Werke, Bd. 6, Martinus Nijhoff, Den Haag 1962, s. 169. Cyt. za polskim przekładem fragmentów Kryzysu... - E. Husserl, Wybór pism, przeł. S. Walczewska, K. Święcicka, Wiedza Powszechna, Warszawa 1993, s. 182.

${ }^{31}$ E. Husserl, Idee czystej fenomenologii i fenomenologicznej filozofii, s. 19-20. 
dziły do degradacji zmysłowości i pominięcia jej rozstrzygającego znaczenia dla naszego poznania. Można zaryzykować tezę, że zasada wszelkich zasad oznacza rehabilitację zmysłowości, skutkującą antyplatońskim poglądem, że archetypiczną formą wszelkiej naoczności jest naoczność spostrzeżeniowa, a ściślej, naoczność spostrzeżenia zewnętrznego, do której ostatecznie odsyłają wszelkie inne rodzaje naoczności, w szczególności naoczność niezmysłowa (istotnościowa). W duchu takiej rehabilitacji zmysłowości można zinterpretować 64. paragraf Logiki formalnej i logiki transcendentalnej, w którym twórca fenomenologii pisze:

Realność ma pierwszeństwo bytowe przed wszelką irrealnością, jako że wszelkie irrealności z istoty odnoszą się wstecznie do rzeczywistej czy możliwej realności ${ }^{32}$.

Z kolei w Doświadczeniu i sądzie znajdujemy szczególny passus, w którym Husserl wyznacza właściwy sens pojęciu „naturalizacji ducha”:

Naturalizacja ducha nie jest wynalazkiem filozofów - mylnie zinterpretowana i stosowana, stanowi podstawowy błąd, ale właśnie tylko wtedy. Podłoże i uzasadnienie ma zaś w tym, że pośrednio lub bezpośrednio wszystko, co realne w świecie, zajmuje miejsce w sferze przestrzenno-czasowej; wszystko jest tu lub tam, a odnośne miejsce można ustalić, gdyż miejsca w ogóle są jak wszystko przestrzenno-czasowe, a więc dają się określić czasowo za pomocą przyrządów fizycznych jak klepsydra, zegar z wahadłem czy inny czasomierz. Tym samym także wszystko niezmysłowe ma udział w zmysłowości, jest bytem ze świata bytującym w jednym przestrzenno-czasowym horyzoncie ${ }^{33}$.

To pierwszeństwo bytowe realności przed idealnością, zgodnie z którym to, co niezmysłowe, ma udział w zmysłowości, należy - rzecz jasna - rozumieć $\mathrm{w}$ sensie fenomenologicznym. Jeżeli $\mathrm{z}$ fenomenologicznego punktu widzenia - jak już zaznaczyliśmy - przedmiot można określić jedynie przez akty, w jakich jest dany, to rozróżnienie przedmiotów realnych i irrealnych musi uwzględniać różnicę między rodzajami prezentujących je aktów, a zatem świat irrealny odsyła do realnego dlatego, że akty, w których dochodzą

${ }^{32}$ E. Husserl, Logika formalna i logika transcendentalna. Próba krytyki rozumu logicznego, przeł. G. Sowinski, IFiS PAN, Warszawa 2011, s. 166.

${ }^{33}$ E. Husserl, Doświadczenie i sąd. Badania nad genealogia logiki, przeł. B. Baran, Fundacja Aletheia, Warszawa 2013, s. 43. 
do prezentacji przedmioty idealne, są ufundowane w aktach prezentujących realności ${ }^{34}$. Skoro zaś przedmioty realne są dane w spostrzeżeniach zmysłowych, bazą wszelkiego poznania jest doświadczenie zmysłowe:

Leży to w naturze rzeczy - pisze Husserl w Badaniach logicznych - że ostatecznie wszystkie [akty] kategorialne opierają się na zmysłowej naoczności, że wręcz naoczność kategorialna, a więc intelektualny wgląd, myślenie w najwyższym sensie, bez fundującej zmysłowości jest niedorzecznością ${ }^{35}$.

Rehabilitacja zmysłowości w żadnym wypadku nie pozostaje w sprzeczności z fenomenologiczną koncepcją oglądu istotnościowego, lecz stanowi jej fenomenologiczne ugruntowanie. W tym kontekście w Badaniach logicznych czytamy:

Idea czystego intelektu, (reinen Intellekts) interpretowana jako „władza" czystego myślenia (tutaj: akcji kategorialnej) i całkowi i i e o d e rwan a od wszelkiej „władzy zmysłowości” mogła zostać wykoncypowana tylko p r z e d elementarną analizą poznania co do jego oczywistego i nieusuwalnego zasobu $^{36}$.

Ta rehabilitacja zmysłowości oznacza w istocie rehabilitację doksa, podniesienie jej do godności pramniemania, co stanowi kwintesencję rozważań Husserla zawartych w Doświadczeniu i sądzie. Zauważmy, że zasadę wszelkich zasad można potraktować jako zasadę oczywistości, przy czym Husserl odchodzi od tradycyjnego, intelektualistycznie zawężonego pojęcia oczywistości jako adekwatnego wglądu, rozszerzając pojęcie oczywistości na wszelką źródłowo samoprezentującą naoczność, w której przedmiot jest dany we „własnej osobie” w taki sam sposób, w jaki był wcześniej domniemany, bez względu na to, czy ta samoprezentacja (Selbstgebung) przedmiotu jest adekwatna, czy też nie ${ }^{37}$. W konsekwencji do aktów oczywistości należy również zaliczyć doświadczenie w "pierwszym i zasadniczym sensie” jako „oczywistość jednostkowych przedmiotów”38. Ściślej doświadczeniem

${ }^{34}$ Zob. P. Łaciak, Struktura i rodzaje poznania „a priori” $w$ rozumieniu Kanta i Husserla, Wydawnictwo Uniwersytetu Śląskiego, Katowice 2003, s. 252.

${ }^{35}$ E. Husserl, Badania logiczne, t. 2: Badania dotyczace fenomenologii i teorii poznania, cz. 2, przeł. J. Sidorek, PWN, Warszawa 2000, s. 219.

36 Tamże.

${ }^{37}$ Zob. E. Husserl, Medytacje kartezjańskie, s. 21-22.

${ }^{38}$ E. Husserl, Doświadczenie i sąd, s. 37. 
$\mathrm{w}$ wąskim sensie jest zewnętrzne spostrzeżenie zmysłowe w znaczeniu samoprezentacji jednostkowego istnienia w modus prostej przeświadczeniowej pewności (Glaubensgewißheit), a w szerszym sensie pojęcie doświadczenia obejmuje nie tylko samoprezentację pewności jednostkowego istnienia, lecz także modalizację tej pewności (przypuszczenie, prawdopodobieństwo, fantazja), przy czym doświadczenie $\mathrm{w}$ węższym znaczeniu jako przeświadczeniowa pewność istnienia okazuje się „szczególnie wyróżnione” ${ }^{39}$. Przeświadczeniowa pewność istnienia bowiem jest praprzeświadczeniem (Urglaube) czy pramniemaniem (Urdoxa), prapostacią wszelkiego uznawania istnienia, przenikającą wszelkie modi żywienia przeświadczenia i związane z nimi sądy, potraktowaną jako podstawa wszelkiego poznania i działania ${ }^{40}$.

Zatem obszar biernej doksa, biernej wiary w istnienie, tego podłoża wiary stanowi fundament nie tylko każdego pojedynczego aktu poznawczego i każdego zwrotu ku poznaniu, każdej oceny bytu, lecz także każdego jednostkowego wartościowania i praktycznego działania w stosunku do bytów - fundament także wszystkiego tego, co się nazywa w konkretnym sensie doświadczeniem i doświadczaniem ${ }^{41}$.

Przeświadczeniowa pewność istnienia świata oznacza zatem „biernq wiare bytowa, która nie ma jeszcze w sobie nic z dokonania poznawczego", i jako taka należy do obszaru pierwotnej pasywności, poprzedzającej wszelką podmiotową aktywnośćc ${ }^{42}$.

W Doświadczeniu i sądzie Husserl, stwierdziwszy, że doświadczenie w węższym sensie oznacza oczywistość jednostkowych przedmiotów, wykazuje, iż jednostkowe przedmioty okazują się substratami wszelkiej aktywności poznawczej, również pierwotnej aktywności logicznej ${ }^{43}$. Logiczne formy mają swe źródło w pierwotnym doświadczeniu, doświadczeniu przedpredykatywnym, które przed wszelkim formowaniem sądowym wykazuje się jednozgodnym przebiegiem, a w tym przebiegu daje się rozpoznać różnicę w sposobie ujmowania zmysłowych treści między substratem a jego określeniami, a zatem do pojęcia substratu Husserl dochodzi w ramach analizy struktury doświadczenia zmysłowego. Ta różnica tkwi u podstaw wszelkiego sądu pre-

\footnotetext{
${ }^{39}$ Tamże, s. 37-38.

${ }^{40}$ Zob. E. Husserl, Idee czystej fenomenologii i fenomenologicznej filozofii, s. 336-342.

${ }^{41}$ E. Husserl, Doświadczenie i sad, s. 60.

42 Tamże, s. 66-68.

${ }^{43}$ Zob. tamże, s. 35-36.
} 
dykatywnego i funduje możliwość syntaktyczno-kategorialnego formowania, opierając się na naturze zmysłowych treści, które mogą być treściami samodzielnymi (substratami) lub niesamodzielnymi (określeniami) ${ }^{44}$. Różnica substratu i określeń rozpatrywana z genetycznego punktu widzenia suponuje pojęcie substratu absolutnego, bezpośrednio doświadczalnego w spostrzeżeniu zmysłowym:

Absolutny substrat - przyznaje Husserl - wyróżnia się [...] tym, że jest doświadczalny wprost, ujmowalny bezpośrednio i że jego eksplikacje przeprowadza się bezpośrednio. Doświadczalne wprost, będąc tym samym substratami w wyróżnionym sensie, są przede wszystkim jednostkowe przedmioty zewnętrznego zmysłowego spostrzeżenia, a więc ciała. Na tym polega jedna z kluczowych zalet spostrzeżenia zewnętrznego jako tego, które daje najpierwotniejsze substraty aktywności doświadczających, a potem eksplikujących predykatywnie ${ }^{45}$.

Absolutne substraty w znaczeniu ciał są przy tym wprawdzie doświadczalne wprost, ale nie przysługuje im absolutna samodzielność, ponieważ są określone jako istnienie w czymś, w świecie, wszechnaturze jako uniwersum ciał, i ową wszechnaturę czy świat Husserl określa jako substrat absolutnie samodzielny, to znaczy taki, który „obejmuje [...] wszystko, sam zaś nie stanowi bycia-w-czymś, nie jest już względną jednością w obszerniejszej wielości" ${ }^{46}$. Husserl zarazem zaznacza, że świat jako absolutny substrat jest wprawdzie substratem samodzielnym, ale, w odróżnieniu od substratów znaczeniu ciał, nie może być przedmiotem bezpośredniego ujmowania ${ }^{47}$. Na tej podstawie Jean Wahl wnioskuje, że zewnętrzne spostrzeżenie zmysłowe jako doświadczenie ciał okazuje się doświadczeniem prostym i pierwotnym, doświadczeniem pierwszego stopnia, podczas gdy doświadczenie świata jako całości jest ujmowaniem drugiego stopnia, ufundowanym we wcześniejszym doświadczeniu jednostkowych przedmiotów ${ }^{48}$. Sam Husserl tak to rozumie:

${ }^{44}$ Zob. V. De Palma, Die Fakta leiten alle Eidetik. Zu Husserls Begriff des materialen Apriori, „Husserl Studies” vol. 30, 2014, s. 211.

${ }^{45}$ E. Husserl, Doświadczenie i sąd, s. 133-134.

${ }^{46}$ Tamże, s. 137.

${ }^{47}$ Zob. tamże, s. 138.

${ }^{48}$ Zob. J. Wahl, Notes sur la première partie de «Erfahrung und Urteil» de Husserl, [w:] Phénoménologie, existence, éd. par H. L. Van Breda, Librairie Armand Colin, Paris 1953, s. $88-89$. 
„Każda pojęciowa prawda zakłada doświadczenie, każda treść pojęciowa zakłada byt doświadczalny, wszelki byt zakłada byt indywidualny" ${ }^{49}$.

\section{Fenomenologia jako przezwyciężenie klasycznego empiryzmu przez prawdziwy empiryzm}

Jean Wahl dostrzega w filozofii Husserla dwie sprzeczne tendencje: idealistyczną, widoczną w szczególności w Ideach I i w Medytacjach kartezjańskich, wywodzącą świat z intencjonalnych dokonań świadomości oraz realistyczną, obecną zwłaszcza w Doświadczeniu i sądzie, stanowiącą konsekwencję postulatów empirystycznych, skutkujących uprzywilejowaniem zewnętrznego spostrzeżenia, w którym są wstępnie dane absolutne substraty w znaczeniu ciał, w czym - jego zdaniem - można rozpoznać „fenomenologiczne uzasadnienie empiryzmu" ${ }^{50}$. Ludwig Landgrebe, polemizując z Wahlem, zaznacza, że w filozofii Husserla mamy raczej do czynienia z rozbieżnością między "programem idealistycznym" fenomenologii a rezultatami szczegółowych analiz, jakie Husserl przeprowadza w szczególności w ostatnim okresie ${ }^{51}$. Zauważmy, że samo pojęcie absolutnych substratów jako ciał, będących przedmiotem bezpośredniego doświadczenia, nie jest wolne od trudności. Zdaniem Landgrebego, a pogląd ten podziela również Lothar Eley, Husserl kwestionuje wprawdzie sensualizm, zgodnie z którym daty zmysłowe okazują się ostatecznymi elementami czy atomami życia świadomościowego, aczkolwiek nigdy całkowicie takiego sensualizmu nie przezwyciężył, dlatego $\mathrm{w}$ fenomenologii transcendentalnej pojęcie tego, co zmysłowe, okazuje się obciążone zasadniczą dwuznacznością ${ }^{52}$ Z jednej strony Husserlowski postulat powrotu do bezpośredniego, pierwotnego doświadczenia, w którym

${ }^{49}$ E. Husserl, Erste Philosophie (1923/24), Teil 2: Theorie der phänomenologischen Reduktion, hrsg. von R. Boehm, [w:] Husserliana, Gesammelte Werke, Bd. 8, Martinus Nijhoff, Den Haag 1959, s. 408.

${ }^{50}$ Zob. J. Wahl, dz. cyt., s. 88. Zob. tenże, Note sur quelques aspects empiristes de la pensée de Husserl, [w:] Phénoménologie, existence, s. 107-135.

${ }^{51}$ Zob. Lettre de M. Ludwig Landgrebe sur un article de M. Jean Wahl concernant «Erfahrung und Urteil» de Husserl, [w:] Phénoménologie, existence, s. 205. Na temat polemiki Landgrebego z Wahlem zob. N. Depraz, dz. cyt., s. 101-106.

${ }^{52}$ Zob. Lettre de M. Ludwig Landgrebe sur un article de M. Jean Wahl concernant «Erfahrung und Urteil» de Husserl, s. 205-206; L. Eley, Nachwort, [w:] E. Husserl, Erfahrung und Urteil. 
jawią się cielesne rzeczy jako substraty, może być w istocie interpretowany sensualistycznie. Jak bowiem zaznacza Eley, można dostrzec analogię między fenomenologią i pozytywizmem logicznym: jak logiczni pozytywiści mówili o zdaniach elementarnych, tak Husserl pyta o „bezpośrednie, ostateczne sądy", które odsyłają do absolutnych substratów w znaczeniu ciał jako „ostatecznych przedmiotów-o-których", pozbawionych wszelkich określen ${ }^{53}$. $\mathrm{Z}$ drugiej jednak strony wszelkie doświadczenie opiera się wprawdzie na samoprezentacji zmysłowej, ale daty hyletyczne nie są izolowanymi atomami psychicznymi, a w pojęciu indywidualnych przedmiotów jako ostatecznych, pozbawionych wszelkich określeń substratów tkwi sprzeczność. Każda data wrażeniowa i każde przeżycie należą bowiem do strumienia świadomości i zachodzą w nieskończonym horyzoncie przeżyciowym, horyzoncie tego, co przedtem, i tego, co później, i jako takie nie mogą uchodzić za coś absolutnie samodzielnego oraz $\mathrm{w}$ pełni określonego. Ponieważ zaś wszelki przedmiot pozostaje w korelacji do przeżyć, przeto ostateczne substraty w znaczeniu indywidualnych przedmiotów (ciał) nie są dane adekwatnie, w sobie i dla siebie, lecz w otwartym horyzoncie jako związku odesłań, wskazującym na dalsze określenia, i to zarówno w horyzoncie wewnętrznym, tj. horyzoncie ich własności presumpcyjnie antycypowanych, jak i w horyzoncie zewnętrznym, który stanowią przedmioty wraz z nimi współdane, współdomniemywane, przedmioty należące do świata jako całości tego, co doświadczane, w konsekwencji zaś nie jest możliwe dotarcie do przedmiotów indywidualnych jako ostatecznych substratów pozbawionych wszelkich określeń ${ }^{54}$.

Pogląd Wahla w kwestii „fenomenologicznego uzasadnienia empiryzmu” na podstawie koncepcji absolutnych substratów w znaczeniu ciał jest tym samym problematyczny, na co wskazuje Landgrebe, zaznaczając, że empiryzm Husserla nie ma konotacji empirystycznych, lecz transcendentalne. Nawiązując do określenia fenomenologii jako pozytywizmu transcendentalnego, które zaproponował Szilasi, Landgrebe nazywa fenomenologię za pomocą jak sam przyznaje - „szokującej charakterystyki”, jaką jest wyrażenie „empi-

Untersuchungen zur Genealogie der Logik, hrsg. von L. Landgrebe, Felix Meiner Verlag, Hamburg 1985, s. 492-494.

${ }^{53}$ Zob. L. Eley, dz. cyt., s. 492-493; E. Husserl, Doświadczenie i sąd, s. 35-36.

${ }^{54}$ Zob. L. Eley, dz. cyt., s. 493-494. W tym kontekście Husserl pisze, że „każde doświadczenie ma swój horyzont doświadczeniowy", to znaczy jest co do istoty nieokreślone, stanowiąc splot tego, co widziane, naocznie dane, i tego, co jedynie domniemywane, antycypowane. Husserl, Doświadczenie i sąd, s. 41. 
ryzm transcendentalny" ${ }^{55}$. Wydaje się, że pojęcie empiryzmu transcendentalnego jest wyrażeniem wewnętrznie sprzecznym jedynie w ramach stanowisk skrajnego empiryzmu oraz skrajnego racjonalizmu, jako że empiryzm transcendentalny okazuje się konsekwencją zakwestionowania zarówno przesądów empirystycznych, jak i intelektualistycznych. Należy jednak zauważyć, że choć fenomenologia nie daje się wpisać ani w tradycyjny racjonalizm, ani w klasyczny empiryzm, jest jej bliższy empiryzm niż racjonalizm. Z historycznofilozoficznego punktu widzenia Husserl docenił wysiłki Locka’a, który ograniczył się do konkretnego opisu tego, co czysto subiektywne, rozpoznając doświadczenie wewnętrzne jako metodę tego opisu, a wychodzący od Locke’a empirystyczny ruch „kulminuje w genialnym Treatise H u m e' a"56. To właśnie tradycja empiryzmu brytyjskiego miała rozstrzygające znaczenie dla wypracowania intuicyjno-wykazującej metody badania aktualnie doświadczającej świadomości, przy czym tradycyjny empiryzm brytyjski nie jest wystarczająco konsekwentny i uniwersalny, ponieważ mieszają się w nim dwie tendencje: pozytywnie psychologiczna i transcendentalnofilozoficzna, a takie pomieszanie prowadzi w prostej linii do psychologizmu ${ }^{57}$. Dlatego zgodnie z zasadą rozwiązywania przeciwieństw w doświadczeniu transcendentalnym $\mathrm{w}$ fenomenologii dochodzi do przezwyciężenia tradycyjnego empiryzmu przez najbardziej uniwersalny empiryzm, dodajmy: przez empiryzm bardziej konsekwentny i radykalny niż dogmatyczny racjonalizm. Można zatem zaryzykować tezę, że wbrew Wahlowi fenomenologia jest nie tyle uzasadnieniem empiryzmu, ile jego przewartościowaniem.

Przezwyciężając przesądy empirystyczne i intelektualistyczne, Husserl wprowadza pojęcie konkretnie wykazywalnej i naocznie doświadczającej świadomości. Według Husserla bowiem świadomość transcendentalna nie jest świadomością w ogóle czy formą świadomości empirycznej, lecz aktualnie doświadczającą świadomością (aktuell erfahrendes Bewusstsein), dodajmy: świadomością pierwotnie doświadczającą siebie w absolutnym samodoświadczeniu, do którego odsyła wszelkie doświadczenie rzeczy, które co do istoty jest doświadczeniem powątpiewalnym, nie zaś absolutnym, jako że

\footnotetext{
${ }^{55}$ L. Landgrebe, Der phänomenologische Begriff der Erfahrung, s. 61. Zasygnalizujmy jedynie, że Natalie Depraz prezentuje ideę empiryzmu transcendentalnego w perspektywie fenomenologii genetycznej. Zob. N. Depraz, dz. cyt., s. 103-113.

${ }^{56}$ E. Husserl, Phänomenologische Psychologie, s. 246.

${ }^{57}$ Zob. tamże.
} 
aktualnie doświadczająca świadomość okazuje się ostatecznym źródłem wykazywania wszelkiego sensu ${ }^{58}$. Husserl pisze bowiem:

[...] jeżeli pytamy o sposób wykazywania w ogóle, jaki zasadniczo wyznacza teza [dotycząca] czegoś transcendentnego bez względu na to, jak byśmy prawomocnie uogólnili jego istotę - to rozpoznajemy, że musi ono być koniecznie dostępne doświ adczeniu, i to nie tylko dla jakiegoś Ja wymyślonego jako jedna z pustych logicznych możliwości, lecz dla jakiegokolwiek Ja a k t u a l n e g o, musi być dostępne jako dająca się wykazać jedność związków doświadczeńn ${ }^{59}$.

Stąd wniosek, że „absolutne uzasadnienie zakłada [...] absolutny ogląd"60, a "redukcja fenomenologiczna otwiera możliwość absolutnego doświadczenia i nauki doświadczeniowej i absolutnej nauki w ogóle" ${ }^{\prime \prime}$. Pojęcie absolutnego doświadczenia czy samodoświadczenia świadomości transcendentalnej, dającego apodyktyczny wgląd w moją świadomość, wgląd, który wyklucza możliwość pomyślenia jej nieistnienia, jest pojęciem kluczowym i stanowi nowość na tle tradycji filozoficznej. Zdaniem Landgrebego Husserl zrywa $\mathrm{z}$ metafizyczną tradycją, że wglądy w wieczne i konieczne prawdy nigdy nie mogą być zaczerpnięte $\mathrm{z}$ doświadczenia, bo doświadczenie ma zawsze do czynienia $\mathrm{z}$ tym, co faktyczne $\mathrm{w}$ znaczeniu kontyngentne. „W świetle tej tradycji absolutne, gwarantujące apodyktyczność doświadczenie byłoby drewnianym żelazem" ${ }^{62}$. Wbrew tej tradycji fenomenologia pod koncepcją doświadczenia transcendentalnego (absolutnego) hołduje "pozytywistycznej zasadzie »normatywnej mocy tego, co faktyczne «", wykluczając możliwość podporządkowania tego, co faktycznie doświadczane, pod apodyktyczność wiecznych prawd, i jako taka - podobnie jak pozytywizm - jest „protestem przeciwko tłumieniu faktyczności przez

\footnotetext{
${ }^{58} \mathrm{Na}$ temat aktualnie doświadczającej świadomości zob. E. Husserl, Transzendentaler Idealismus. Texte aus dem Nachlass (1908-1921), hrsg. von R. D. Rollinger in Verbindung mit R. Sowa, [w:] Husserliana, Gesammelte Werke, Bd. 36, Kluwer Academic Publishers, Dordrecht-Boston-London 2003, s. 76-78.

${ }^{59}$ E. Husserl, Idee czystej fenomenologii i fenomenologicznej filozofii, s. 145.

${ }^{60}$ E. Husserl, Erste Philosophie (1923/24), Teil 2, s. 367.

${ }^{61}$ Tamże, s. 362.

${ }^{62}$ L. Landgrebe, Husserls Abschied vom Cartesianismus, [w:] tenże, Der Weg der Phänomenologie. Das Problem einer ursprünglichen Erfahrung, Gütersloher Verlagshaus Gerd Mohn, Gütersloh 1963, s. 172.
} 
myślenie metafizyczne"63. Kwestionując to myślenie, Husserl pisze wprost: "Absolut, który odsłaniamy, jest absolutnym "faktem «"64.

Doświadczenie transcendentalne okazuje się $\mathrm{w}$ istocie samodoświadczeniem „Ja jestem”, a „zdanie "Ja jestem“ musi być prawdziwą $\mathrm{zasadac}$ wszelkich zasad i pierwszym zdaniem wszelkiej prawdziwej filozofii”" ${ }^{2}$. Chodzi przy tym o doświadczenie faktu „Ja jestem”: świadomość transcendentalna nie jest rozumiana $\mathrm{w}$ znaczeniu niedoświadczalnego warunku możliwości wszelkiego doświadczenia, lecz w sensie faktycznie doświadczającej subiektywności, czy też, jak powie Landgrebe, „pola doświadczenia transcendentalnego”, a właściwie pola „faktyczności doświadczenia transcendentalnego" ${ }^{66}$, do którego odsyła wszelkie poznanie, ponieważ wszelkie poznanie dokonuje się w obrębie absolutnego doświadczenia "Ja jestem”. W tym kontekście warto przywołać komentarz Jean-Paula Sartre’a, który zauważa:

W rzeczywistości absolut jest tu nie tyle rezultatem logicznej konstrukcji w dziedzinie poznania, ile podmiotem najbardziej konkretnego z doświadczeń. I nie jest wcale relatywny względem tego doświadczenia, ponieważ po prostu jest tym doświadczeniem. Jest więc absolutem niesubstancjalnym ${ }^{67}$.

Tak więc doświadczenie faktu mnie samego jest nieodłączne od faktu tegoż doświadczenia, faktu apodyktycznego, którego nie dotyka nawet dająca się wykazać możliwość nieistnienia świata, faktu egotycznego, że doświadczam, faktu, który nie może być zanegowany, nawet jeżeli treść doświadczenia w dalszym jego przebiegu zostanie skorygowana czy unieważniona ${ }^{68}$.

Najpierw (i przede wszystkim, cokolwiek można sobie pomyśleć) istnieję j a. Owo „Ja istnieję" stanowi dla mnie [...]prapodstawę intencjo-

\footnotetext{
${ }^{63}$ Tamże, s. 173.

${ }^{64}$ E. Husserl, Zur Phänomenologie der Intersubjektivität. Texte aus dem Nachlass, Teil 3: 1929-1935, hrsg. von I. Kern, [w:] Husserliana, Gesammelte Werke, Bd. 15, Martinus Nijhoff, Den Haag 1973, s. 403.

${ }^{65}$ E. Husserl, Erste Philosophie (1923/24), Teil 2, s. 42.

${ }^{66}$ L. Landgrebe, Husserls Abschied vom Cartesianismus, s. 174, 180.

${ }^{67}$ J.-P. Sartre, Byt i nicość. Zarys ontologii fenomenologicznej, przeł. J. Kiełbasa, P. Mróz, R. Abramciów, R. Ryziński, P. Małochleb, Wydawnictwo Zielona Sowa, Kraków 2007, s. 18.

${ }^{68}$ Zob. E. Husserl, Einleitung in die Philosophie. Vorlesungen 1922/23, hrsg. von B. Goossens, [w:] Husserliana, Gesammelte Werke, Bd. 35, Kluwer Academic Publishers, DordrechtBoston-London 2002, s. 69-71.
} 
n a ln ą moje g o ś w i a t a, przy czym nie mogę nie dostrzegać, że „obiektywny” świat, „świat dla nas wszystkich” (jako świat w tym sensie cechujący się dla mnie ważnością) jest „moim” światem. [...] jest to p r a f a k t, k tó r e m u m uszę s prostać, od którego jako filozof nie mam prawa ani przez moment odwracać oczu ${ }^{69}$.

Fenomenologia musi zatem wychodzić od egotycznego prafaktu „Ja jestem", faktu mojego doświadczenia, faktu uniwersalnego, bo wszelkie zjawiska, przeżycia, daty podlegają warunkowi bycia moimi, a transcendentalna sfera mojego „Ja jestem” stanowi jedyne w swoim rodzaju połączenie faktyczności i absolutności, nie dając się rozumieć za pomocą przeciwieństwa: przypadkowe - konieczne w znaczeniu zapożyczonym z tradycji:

Absolut ma w sobie samym swoją podstawę [...]. Jego konieczność nie jest koniecznością istotową, która pozostawia miejsce dla tego, co przypadkowe. Wszelkie istotowe konieczności są momentami jego faktyczności, są sposobami jego funkcjonowania w odniesieniu do samego siebie - sposobami, w jakich rozumie on samego siebie lub może rozumiećc ${ }^{70}$.

Pojęcie absolutnego faktu, implikując prymat rzeczywistości nad możliwością, jest rezultatem wglądu w faktyczny fundament poznania istotnościowego, wglądu wyrażonego w formule: „Odnośnie do mnie i świata rzeczywistość poprzedza każdą możliwość" ${ }^{\prime 1}$, wglądu, który prowadzi, żeby się posłużyć wyrażeniem Vittorio De Palmy, do empiryzmu ejdetycznego ${ }^{72}$. Pierwotny fakt mojego doświadczenia, fakt mojego „Ja jestem” jest faktem ir-

${ }^{69}$ E. Husserl, Logika formalna i logika transcendentalna, s. 230-231.

${ }^{70}$ E. Husserl, Zur Phänomenologie der Intersubjektivität, s. 386.

${ }^{71}$ Tamże, s. 519.

${ }^{72}$ Zauważmy, że Maurice Merleau-Ponty pisze również o faktycznym fundamencie praw a priori, twierdząc, że to, co uchodzi za prawdę a priori ,jest już tylko formalnym wyrazem fundamentalnej przypadkowości - skutkiem faktu, że jesteśmy w świecie”, tak że „prawdy a priori nie są niczym innym niż wyjaśnieniem pewnego faktu: faktu doświadczenia zmysłowego”. M. Merleau-Ponty, Fenomenologia percepcji, przeł. M. Kowalska, J. Migasiński, Fundacja Aletheia, Warszawa 2001, s. 241, 242. W filozofii Merleau-Ponty’ego, jak zauważa De Palma, dochodzi jednak do zakwestionowania rozróżnienia między prawdami apriorycznymi i faktycznymi, skutkującego przekształceniem ejdetyki w analizę egzystencjalną bądź, jak to ujmuje Natalie Depraz - empiryzmem ontologicznym, podczas gdy Husserl absolutny fakt „Ja Jestem” uznaje za granicę poznania ejdetycznego, w żaden sposób nie kwestionując możliwości takiego poznania, lecz reinterpretując je w duchu empiryzmu transcendentalnego czy też empiryzmu ejdetycznego. Zob. V. De Palma, Ist Husserls Phänomenologie ein transzendentaler Idealismus?, 
racjonalnym, stanowiącym granicę racjonalności, faktem, którego nie można potraktować jako przypadkowej realizacji jakiejś ejdetycznej możliwości; przeciwnie, wszelkie ejdetyczne możliwości są w nim zakorzenione. W konsekwencji faktyczność „Ja jestem” ma charakter absolutny w tym znaczeniu, że poprzedza wszelkie ejdetyczne możliwości, które dopiero w nim się konstytuują i służą jego rozjaśnieniu ${ }^{73}$.

W ten sposób aktualnie doświadczająca świadomość, która wyraża się w absolutnym fakcie „Ja jestem”, kładzie kres separacji między tym, co empiryczne, a tym, co transcendentalne, między tym, co przypadkowe, a tym, co konieczne, między tym, co faktyczne, a tym, co ejdetyczne; jako taka, ma rozstrzygające znaczenie dla zrozumienia Husserlowskiej idei prawdziwego, radykalnego czy najbardziej uniwersalnego i najbardziej konsekwentnego empiryzmu.

\section{Bibliografia}

De Palma V., Die Fakta leiten alle Eidetik. Zu Husserls Begriff des materialen Apriori, „Husserl Studies” 2014, vol. 30, s. 195-223.

De Palma V., Ist Husserls Phänomenologie ein transzendentaler Idealismus?, „Husserl Studies" 2005, vol. 21, s. 183-206.

Depraz N., Transcendentalna empiryczność fenomenologii, przeł. A. Dwulit, [w:] Główne problemy współczesnej fenomenologii, red. J. Migasiński, M. Prokropski, Wydawnictwo Uniwersytetu Warszawskiego, Warszawa 2017, s. 97-129.

Eley L., Nachwort, [w:] E. Husserl, Erfahrung und Urteil. Untersuchungen zur Genealogie der Logik, hrsg. von L. Landgrebe, Felix Meiner Verlag, Hamburg 1985, s. $479-518$.

Husserl E., Badania logiczne, t. 2: Badania dotyczace fenomenologii i teorii poznania, cz. 2, przeł. J. Sidorek, PWN, Warszawa 2000.

Husserl E., Briefwechsel, [w:] Husserliana, Dokumente, Bd. 3, in Verbindung mit E. Schuhmann herausgegeben von K. Schuhmann, Teil 7: Wissenschaftlerkorrespondenz, Springer-Science+Business Media, Dordrecht 1994.

s. 200; tenże, Die Fakta leiten alle Eidetik. Zu Husserls Begriff des materialen Apriori, s. 206;

N. Depraz, dz. cyt., s. 103-104.

${ }^{73}$ Zob. L. Landgrebe, Husserls Abschied vom Cartesianismus, s. 177, 196. Szerzej na temat absolutnego faktu zob. P. Łaciak, Anonimowość jako granica poznania w fenomenologii Edmunda Husserla, Wydawnictwo Uniwersytetu Śląskiego, Katowice 2012, s. 188-199. 
Husserl E., Die Krisis der europäischen Wissenschaften und die transzendentale Phänomenologie. Eine Einleitung in die phänomenologische Philosophie, hrsg. von W. Biemel, [w:] Husserliana, Gesammelte Werke, Bd. 6, Martinus Nijhoff, Den Haag 1962.

Husserl E., Doświadczenie i sąd. Badania nad genealogia logiki, przeł. B. Baran, Fundacja Aletheia, Warszawa 2013.

Husserl E., Einleitung in die Philosophie. Vorlesungen 1922/23, hrsg. von B. Goossens, [w:] Husserliana, Gesammelte Werke, Bd. 35, Kluwer Academic Publishers, Dordrecht-Boston-London 2002.

Husserl E., Erste Philosophie (1923/24), Teil 2: Theorie der phänomenologischen Reduktion, hrsg. von R. Boehm, [w:] Husserliana, Gesammelte Werke, Bd. 8, Martinus Nijhoff, Den Haag 1959.

Husserl E., Filozofia jako ścisła nauka, przeł. W. Galewicz, Fundacja Aletheia, Warszawa 1992.

Husserl E., Idea fenomenologii. Pięć wykładów, przeł. J. Sidorek, PWN, Warszawa 1990.

Husserl E., Idee czystej fenomenologii i fenomenologicznej filozofii. Ksiega pierwsza, przeł. D. Gierulanka, PWN, Warszawa 1975.

Husserl E., Logika formalna i logika transcendentalna. Próba krytyki rozumu logicznego, przeł. G. Sowinski, IFiS PAN, Warszawa 2011.

Husserl E., Medytacje kartezjańskie, przeł. A. Wajs, PWN, Warszawa 1982.

Husserl E., Phänomenologische Psychologie. Vorlesungen Sommersemester 1925, hrsg. von W. Biemel, [w:] Husserliana, Gesammelte Werke, Bd. 9, Martinus Nijhoff, Den Haag 1962.

Husserl E., Transzendentaler Idealismus. Texte aus dem Nachlass (1908-1921), hrsg. von R. D. Rollinger in Verbindung mit R. Sowa, [w:] Husserliana, Gesammelte Werke, Bd. 36, Kluwer Academic Publishers, Dordrecht-Boston-London 2003.

Husserl E., Wybór pism, przeł. S. Walczewska, [w:] K. Święcicka, Husserl, Wiedza Powszechna, Warszawa 1993.

Husserl E., Zur Phänomenologie der Intersubjektivität. Texte aus dem Nachlass, Teil 3: 1929-1935, hrsg. von I. Kern, [w:] Husserliana, Gesammelte Werke, Bd. 15, Martinus Nijhoff, Den Haag 1973.

Landgrebe L., Der phänomenologische Begriff der Erfahrung, [w:] tenże, Faktizität und Individuation. Studien zu den Grundfragen der Phänomenologie, Felix Meiner Verlag, Hamburg 1982, s. 58-70.

Landgrebe L., Husserls Abschied vom Cartesianismus, w: tenże, Der Weg der Phänomenologie. Das Problem einer ursprünglichen Erfahrung, Gütersloher Verlagshaus Gerd Mohn, Gütersloh 1963, s. 163-206.

Lettre de M. Ludwig Landgrebe sur un article de M. Jean Wahl concernant «Erfahrung und Urteil» de Husserl, [w:] Phénoménologie, existence, éd. par H. L. Van Breda, Librairie Armand Colin, Paris 1953, s. 205-206. 
Levinas E., Ruina przedstawienia, [w:] tenże, Odkrywając egzystencję $z$ Husserlem $i$ Heideggerem, przeł. E. Sowa, IFiS PAN, Warszawa 2008, s. 129-141.

Łaciak P., Anonimowość jako granica poznania w fenomenologii Edmunda Husserla, Wydawnictwo Uniwersytetu Śląskiego, Katowice 2012.

Łaciak P., Struktura i rodzaje poznania „a priori” w rozumieniu Kanta i Husserla, Wydawnictwo Uniwersytetu Śląskiego, Katowice 2003.

Merleau-Ponty M., Fenomenologia percepcji, przeł. M. Kowalska, J. Migasiński, Fundacja Aletheia, Warszawa 2001.

Pažanin A., Wissenschaft und Geschichte in der Phänomenologie Edmund Husserls, Martinus Nijhoff, Den Haag 1972.

Ricoeur P., Fenomenologia i hermeneutyka. Wychodzac od Husserla..., przeł. M. Drwięga, [w:] Fenomenologia francuska. Rozpoznania/interpretacje/rozwinięcia, red. J. Migasiński, I. Lorenc, IFiS PAN, Warszawa 2006, s. 194-233.

Sartre J.-P., Byt i nicość. Zarys ontologii fenomenologicznej, przeł. J. Kiełbasa, P. Mróz, R. Abramciów, R. Ryziński, P. Małochleb, Wydawnictwo Zielona Sowa, Kraków 2007.

Scheler M., Postawa fenomenologiczna, przeł. A. Węgrzecki, [w:] A. Węgrzecki, Scheler, Wiedza Powszechna, Warszawa 1975, s. 131-138.

Szilasi W., Einführung in die Phänomenologie Edmund Husserls, Max Niemeyer Verlag, Tübingen 1959.

Tugendhat E., Der Wahrheitsbegriff bei Husserl und Heidegger, Walter de Gruyter \& Co, Berlin 1967.

Wahl J., Notes sur la première partie de «Erfahrung und Urteil» de Husserl, [w:] Phénoménologie, existence, éd. par H. L. Van Breda, Librairie Armand Colin, Paris 1953, s. 77-105.

Wahl J., Note sur quelques aspects empiristes de la pensée de Husserl, [w:] Phénoménologie, existence, éd. par H. L. Van Breda, Librairie Armand Colin, Paris 1953, s. 107-135.

\section{Abstract \\ Transcendental Phenomenology as True Empiricism}

The aim of the article is to demonstrate that phenomenology can be understood as true empiricism, that is to say, the empiricism free from naturalistic implication. This empiricism is a result of criticism of the rationalistic prejudices and it begins with a statement of the absolute fact of my transcendental consciousness (the fact of experience of my "I am"). According to Husserl, the principle of all principles of phenomenology means that actually experiencing consciousness plays a fundamental 
role in our knowledge as it is the ultimate justification and an original place of the demonstration of all sense. In this context, the author points out that principle of all principles may be considered as a postulate of empiricism, because all knowledge must be based on the absolutely given experience of the fact of "I am". In contrast to traditional empiricism, phenomenological empiricism attempts to the solution of the opposition between empiricism and rationalism in the traditional sense and this solution takes place in the transcendental experience so that phenomenology, as noted by Ludwig Landgrebe, appears to be transcendental empiricism.

Keywords: Edmund Husserl, Ludwig Landgrebe, phenomenology, transcendental empiricism, transcendental experience, fact of "I am" 